\title{
Fostering function of speaking talk as performance
}

ISSN 2657-9774; https://doi.org/10.36534/erlj.2021.01.08

Božena Horváthová*, Martina Galbová**

*Constantine the Philosopher University in Nitra, Slovakia; bhorvathova@ukf.sk

** Základná škola s materskou školou Žabokreky nad Nitrou, Slovakia; galbova.martina@gmail.com

\begin{abstract}
The paper deals with the function of speaking Talk as Performance, which requires special teaching approaches. The theoretical part provides information about adolescent language learners and guidelines for teaching them. The age of the learners at this level, the basic characteristics, the proficiency level based on Common European Framework of References for Languages (CEFR) and International Standard of Classification (ISCED) are discussed as well. Further on, attention is paid to the language skill speaking and basic methodological approaches to speaking are tackled. Finally, the function of speaking Talk as Performance and its implementation to in-class teaching is discussed. The research focuses on the application of three research methods content analysis, observation and interview, the purpose of which is to find which activities promote the function Talk as Performance in two different textbooks used by teenage language learners and to investigate how the function is taught in two different English classes by two different teachers. Subsequently, the research results are analysed within each method.
\end{abstract}

Key words: adolescent language learner, speaking skill, functions of speaking, talk as performance, $T E F L$, content analysis, observation, interview

\section{Introduction}

Teaching and learning speaking skill is a complex process. We speak for many reasons in various situations for different purposes. On one occasion we may want to talk to friends, another time we travel to a foreign country and want to buy a souvenir or ask someone for directions. And then, we might find ourselves at the wedding of our foreign friends and are asked to give a speech. The latter situation represents the function of speaking Talk as Performance. Being able to communicate for this purpose, the English teaching and learning process should involve specific activities for the development of this function. Therefore, the aim of this paper is to explore how the function Talk as Performance is taught to adolescent learners at lower secondary level.

According to International Standard of Classification ISCED (2011) the age of learners entering ISCED 2 level is usually 10 years. As lower secondary education in Slovakia lasts for five years, after completion of ISCED 2, learners are usually 14 up to 16 years old. The term adolescent or teenager can be applied for learners of lower and upper secondary school level, which means learners from 10 up to 18 years.

Harmer (2007) sees the potential of adolescents in their creative attitudes towards learning and their ability to use abstract ideas for expressing themselves. However, they are still depending on the teacher's guidance that produces intellectual activities in order to make them solve contrasting concepts (ibid). Dörnyei (2005) found out that adolescents are more likely exposed to analysing language when it comes to explaining rather the using memory components like pictures.

Some other characteristics of adolescent English learners are suggested by Scrivener (2011) describing them as enthusiastic learners who might start see themselves as important for the world. $\mathrm{He}$ also adds that they appreciate tasks to be well organized and to fulfil their interests. As Harmer (2007) says, with correct objectives during English language lessons, they are the most exciting learners to be taught. He can see positives in their understanding of why they are learning and at the 
same time in their willingness to do what they are asked. However, Brown (2004) considers teaching adolescents to be a kind of mystery, especially for teachers of languages.

\section{Theoretical background \\ Teaching English to adolescents}

Although the learning capability of adolescents becomes greater than that of young learners', Ur (1996) sees difficulties in motivating and managing them. For many authors, adolescents are those who are difficult to be taught. Ur (1996) suggests making questionnaires about their expectations in order to prevent weak relationships between teachers and their learners. In order to keep them motivated, it is necessary for teachers to provoke their interests by using exciting materials and topics to be discussed (Harmer, 2007). Such topics are according to British council (n.d.) cars, music, sports, TV, movies, TV series, fashion and celebrities. Another way how to keep them motivated is to display situations in which English is needed (British council, [online] n.d.).

As the contagious topics of their interest have been already mentioned, there are many activities such as watching English videos including those interests or using their favourite TV shows to help them master their language skills (ibid). This is agreed also by another teacher of adolescents, Saumell (2014), who adds that although it might be impossible to cover all individual interests, there should be time to recognise a majority of them. Despite this fact, adolescents might pose a bunch of difficulties for a teacher who does not know how to handle this particular group of learners. Saumell (2014) suggests some more ideas on how to be successful in teaching them. First of all, she suggests building a positive in-class rapport otherwise they will be complaining about everything the teacher says. Once the objectives of the lesson are stated, learners will appreciate being given an option to choose the way how to use their ideas, e.g. using tools to make a presentation on a specific topic or choosing their own topic according their interest in order to enhance their fluency. Scrivener (2011) adds that it is better to ask them to bring their own materials they want to work with. As they are still very playful and competitive, Saumell (2014) suggests the idea to integrate challenges instead of stereotype classes, e.g. creating more difficult tasks, competitions or open-ended tasks that have multiple solutions. Lastly, adolescents suffer from short attention span, which leads to quick boredom; therefore, it might be intriguing to replace routines with new varieties of classroom management.

Budden (2019) alongside with Skeffington (2004) agree that authenticity is a tool to make teenagers talk. Skeffington (2004) pays attention to the different personalities of learners. She suggests that if learners have an opportunity to talk about authentic and personal topics they are motivated to express themselves in language that is not yet familiar to them. Budden (2019) sees teenagers as curious young people and therefore recommends using photos as an authentic means of expression. However, she is not talking only about learners' personal photos to be described, but suggests using teachers' ones. She states that personalizing increases their curiosity level, which generates plenty of words.

Scrivener (2011) proclaims that all materials dedicated for mastering language skills must be upto-date sources corresponding to their age and proficiency level. Furthermore, as they are standing on the border between childhood and adulthood, it is better to avoid childish material that will be rejected (ibid). The Lower Secondary Teacher Guide (2006: 2-3) states that using a variety of teaching techniques contributes to encouraging learners' language learning. It suggests using strategies such as role play, drama, class discussion and debate, problem-solving activities, audio-visual activities, explanations, lectures, reading aloud, guest speakers, group works, etc. Last but not least Scrivener (2011: 326) recommends various individual activities and activities requiring active participation.

\section{Proficiency level at lower secondary school level}

According to Brown (2004) it is necessary for teachers to be familiar with learners' level of proficiency as it represents a base for creating curricula and textbooks. Two reference documents are 
addressed in the subsequent paragraphs - Common European Framework of References for Languages (CEFR) and International Standard of Classification (ISCED).

As the paper focuses on learners whose proficiency level is $A 2$ according to CEFR, these specific criteria will be considered in the following lines. CEFR (2011: 58-60) provides four different illustrative scales available for $\mathrm{A} 2$ level including oral production, monologue describing experience, public announcements and addressing audience. The following descriptors are closely connected to the function of speaking called Talk as Performance, which is the focus of our research.

According to the oral production descriptor (CEFR 2011: 58) a learner "can give a simple description or presentation of people, living or working conditions, daily routines, likes/dislikes, etc. as a short series of simple phrases and sentences linked into a list." According to the public announcements descriptor (CEFR 2011: 60) a learner "can deliver very short, rehearsed announcements of predictable, learnt content which are intelligible to listeners who are prepared to concentrate."

According to the sustained monologue descriptor (CEFR 2011: 59) when describing experience, a learner can:

- tell a story or describe something in a simple list of points;

- describe everyday aspects of his environment e.g. people, places, a job or study experience;

- give short, basic descriptions of events and activities;

- describe plans and arrangements, habits and routines, past activities and personal experiences;

- use simple descriptive language to make brief statements about and compare objects and possessions;

- explain what he/she likes or dislikes about something;

- describe his/her family, living conditions, educational background, present or most recent job;

- describe people, places and possessions in simple terms.

According to the addressing audience descriptor (CEFR 2011: 60) a learner can:

- give a short, rehearsed presentation on a topic pertinent to his everyday life, briefly give reasons and explanations for opinions, plans and actions;

- cope with a limited number of straight forward follow up questions;

- give a short, rehearsed basic presentation on a familiar subject, answer straight forward follow up questions if he/she can ask for repetition and if some help with the formulation of his reply is possible.

In Slovakia, teachers are usually regulated by the already mentioned International Standard of Classification ISCED 2, a document which consists of educational areas with corresponding subjects. English language is part of the area called Language and Communication in ISCED 2. The common denominator of this area is a language that is seen as a source of personal and cultural enrichment, as a tool needed for thinking and communicating and as a means important for expressing emotions (ISCED 2, 2014). Furthermore, this document (2014: 2-3) defines the following aims applicable to the subject English language:

- using general competences which are not specific to language, but are necessary for different activities, including language activities;

- using communicative language competences in such a way that the communication intention is realized in a limited way;

- processing spoken or written text as a listener or reader in receptive language activities and strategies (listening comprehension, reading comprehension);

- producing oral or written texts in productive and interactive language activities and strategies (oral, written);

- using spoken and written texts in communication situations for specific functional goals.

As Lindstromberg (2004) states, teachers might think they know their class proficiency level, interests and background, but when it comes to choosing speaking activities special attention must be given to their appropriateness. Although many speaking topics and tasks can be adapted to 
different proficiency levels, some of them might cause the learners difficulties to express themselves (Hadfield and Hadfield 2008).

\section{Function of speaking talk as performance}

Since researching speaking is a broad topic, it requires a particular focus, which is, in the case of our research, aimed at the functions of speaking. The authors, who have investigated functions of speaking and reasons for communication, are Brown and Yule (1983) and Richards (2008). Brown and Yule (1983) distinguish two types of communication, which are talk as Interaction and Talk as Transaction. However, Richards (2008) based on his workshops with teachers includes a third function which is Talk as Performance. As he points out, all three functions require a different teaching approach as they are distinct in their form.

Talk as Performance is the function, which focuses on preparing learners for "real-life" presentation (Thornburry 2005: 94). As he states, sooner or later, whether in school or job-related activities, learners might find themselves standing in front of an audience giving a speech. Richards (2008) states that this function works based on the principle of transferring the statement to listeners. Usually, it is done through monologue, which has a discernible format and is similar to written language (ibid). The task of that statement is then to inform, influence and sometimes even entertain the audience (Baumeyer 2019). Jones (1996 cited in Richards 2008: 27) claims that "spoken text of this kind have identifiable generic structures: the language is predictable, the speaker must include all necessary information in the text the emphasis focuses on form and accuracy."

Gondová (2013: 44) and Richards (2008: 28) agree, that besides being able to speak, there are other skills involved in spoken performance such as creating a credible effect on the audience; maintaining audience engagement; presenting information in an appropriate sequence; and using an appropriate format, opening and closing and language system. Lightfoot (n.d.) also includes using appropriate body language, which is an inseparable part of performance and when used inappropriately, the impression on an audience might be unattractive.

Gondová (2013) uses different terminology compared to Richards' term Talk as Performance and names this function a planned or unplanned monologue. However, the contents of both terms correspond. Planned monologue refers to speech, which might be prepared in written form that helps learners to plan their speech and afterwards practice their oral performance. The aim of the task is to gradually learn how to create a clear and comprehensible description and a presentation that is logically organized into a coherent text as well as to highlight the main ideas giving all the necessary details (Gondová 2013). Topics of the descriptions and presentations the learners create should be chosen by the learners themselves, reflecting their interests as this increase the communication value of their speech (ibid).

The second type which Gondová (2013) distinguishes is an unplanned or spontaneous monologue, the purpose of which is preparing the learners to produce a coherent speech describing their experiences accompanied with feelings and reactions. She proclaims that learners should be able to talk about a film or a book or describe their dreams, hopes and ambitions, various events, tell a story, etc. To make it more interesting she recommends group work, where each participant tells the story concerning the topic and afterwards one spokesperson presents the best story in front of the class. This approach might be attractive and comfortable for learners.

Learning how to speak in public is very important because learners might find it useful throughout their lives. However, it is very often accompanied with anxiety, stress and stage fright, which might lead to glossophobia defined as a fear of public speaking (Black 2019). Teaching and promoting Talk as Performance in an English lesson is considered the best practice. Black (2019) adds that speaking in front of audience contributes to confident use of English.

Once the English class focuses on developing Talk as Performance, teachers should firstly provide a model example of what it should look like. Richards (2008) recommends playing videos, records or even written examples. What Richards (2008: 35) mentions next, is answering the questions "who is the audience, what is the speakers' purpose, what kind of information the audience expects." Richards (2008: 27) suggests activities such as classroom presentations; giving a report about events; 
giving a welcome speech; presentations of ideas; public announcements; retelling a story; speeches, and storytelling.

\section{Research methodology}

The research methodology consists of three steps that will provide three different perspectives on teaching the function of speaking Talk as Performance. First, content analysis of textbooks and a workbook used by 9th graders will reveal how many activities suggested by the textbook authors focus on this function of speaking. Second step will disclose how the activities developing Talk as Performance are taught in real English lessons. It will be achieved through fifteen non-participant observations. Last step, an interview, will provide teachers' points of view towards teaching speaking and its function Talk as Performance.

\section{Research aims and research questions}

In order to find out how the speaking function is taught, the following research aims and research questions were formulated:

- to find out what types of activities promote Talk as Performance;

- to find out whether teachers focus on the development of the function of speaking Talk as Performance and how they promote this function;

- Which activities found in the analysed textbooks and workbook promote Talk as Performance?

- Do the teachers implement activities focusing on the function of speaking Talk as Performance? If yes, how do they implement them? If not, why they do not implement them?

\section{Research sample}

The research was conducted with learners of lower secondary level, precisely 9th graders. The reason for this choice is that 9th graders should already have A2 proficiency level and their speaking skills should be on a higher level compared to lower grades. The research was conducted at two different schools. The research at school A and B was conducted in January and February 2020. Before conducting the research, both teachers and head masters approved the conditions of the research. Both of the qualified teachers of English, with teaching experience of 15 and 30 years, also agreed to participate in interviews conducted at the end of observation. The reason for choosing two different teachers instead of conducting 15 observations with one teacher, was to find out if there are any differences in teaching approaches towards the function of speaking Talk as Performance.

Besides the observation and interviews, English textbooks and workbooks, which are used by 9th graders at these two schools, were analysed. School A uses the textbook Project 5, 3rd edition written by Tom Hutchinson $(2010,2009)$ consisting of six units. The units are very extensive. Each unit consists of four different sections A, B, C, D and each section includes exercises aimed at practicing pronunciation, vocabulary, grammar, and communicative skills. After covering the four sections, pages focusing on culture, English across the curriculum, a revision page, project, and a song follow. School B uses a textbook and a workbook More! 3 written by Herbert Puchta and Jeff Stranks (2014) consisting of 12 units. Each unit consists of the sections: introduction, dialogue work or text work (alternated in every second unit), vocabulary and grammar, which covers a double page in every single unit, communicative skills paying attention to reading, listening and speaking. Finally, sections on culture, Content Language Integrated Learning (CLIL) and "Check your progress" can found after every second unit.

\section{Data collecting instruments}

In order to guarantee triangulation of the data and methods, three different data collecting instruments were applied. The first one, content analysis, is characterized as a summary of "main contents of data and their message" (Cohen et al. 2007: 494). Content analysis might be applied to any kind of larger written texts. Cohen et al. (2007) provide a procedure for content analysis which 
consists of several steps: first, finding the written material to be analysed, after reading the text, the researcher is supposed to create codes that emerge from the text; afterwards these codes must be placed into the prearranged categories. The content analysis was conducted with two textbooks and one workbook, since school A does not use a workbook during the lessons. Firstly, all speaking activities were analysed with a focus on the functions of speaking. Only those activities are classified, named and counted which belong to Talk as Performance activities. Under the category Talk as Performance, activities found in textbooks and workbooks which represent different codes were summarised in tables. After filling in the tables, qualitative analysis providing reasons for the division of activities followed. Furthermore, other codes - form of work and examples were described. By conducting the content analysis, the most common activities of the function Talk as Performance provided by English textbooks were identified.

The non-participant semi-structured observation was conducted after the content analysis of activities in order to find out what the reality of teaching speaking in English lessons is, with focus on the function of speaking Talk as Performance. The main aim was to observe whether teachers involve the textbook and workbook activities or whether they use their own activities promoting Talk as Performance. Furthermore, it was observed whether the English lessons provide some situations for potential development of Talk as Performance. All observed classes were regular ones. We did not ask teachers to implement any extra speaking activities as we wanted to capture the real lessons. During the observation, the main focus was given to speaking activities promoting Talk as Performance, however, short descriptions of the content of the English lessons are provided as well. Data collection was provided through filling in an observation sheet, consisting of basic information such as the date, name of school and class. The second part of the observation sheet focused on activities promoting the function of speaking Talk as Performance. Information included the type of activity, speaking as a main or extra activity, form of work, materials, examples, performance of learners, reactions of learners and potential situations for developing Talk as Performance. After conducting all observations, categories and codes resulting from the observation notes were processed for further analysis.

Finally, a semi-structured interview was conducted, as it is based on asking prearranged questions which might vary depending on the respondent's answers. The interview with both teachers was conducted after the completion of all observations at school A and B. The aim of the interview was to find out the teachers' attitudes towards teaching speaking in general. But the main focus was mainly on the implementation of activities promoting the function of speaking Talk as Performance and situations in which they are applied. Moreover, we tried to find out what materials teachers use for teaching this function. With the permission of the teachers, interviews were recorded in order to keep all the answers as accurate as possible. There was no piloting of instruments being done prior to administering them to ensure their validity and reliability.

\section{Research results}

Before starting the content analysis, a table within the category Talk as Performance was created. All activities, which correspond to this function, were classified. Within the coding system, the type of activities and the number of their occurrence were distinguished. The first content analysis was conducted with the textbook Project 5 and the second with the textbook and workbook More! 3. In both textbooks and workbook the same categories, but different codes, occur within the activity types.

Table 1: Summary of content analysis

\begin{tabular}{|l|c|c|c|}
\hline \multicolumn{4}{|c|}{ Category: TALK AS PERFORMANCE } \\
\hline & Project 5 & \multicolumn{2}{c|}{ More! 3 } \\
\hline Code and Activity & Textbook & Textbook & Workbook \\
\hline 1. PROJECT \\
PRESENTATION
\end{tabular}




\begin{tabular}{|l|c|c|c|}
\hline $\begin{array}{l}\text { 2. PRESENTATION OF } \\
\text { IDEAS }\end{array}$ & 7 & 1 & 0 \\
\hline 3. STORYTELLING & 2 & 0 & 0 \\
\hline $\begin{array}{l}\text { 4. CLASSROOM } \\
\text { PRESENTATION }\end{array}$ & 0 & 4 & 0 \\
\hline 5. REVIEW & 0 & 1 & 0 \\
\hline 6. GIVING A SPEECH & 0 & 0 & 1 \\
\hline TOTAL & 15 & $\mathbf{7}$ & $\mathbf{1}$ \\
\hline
\end{tabular}

\section{Content analysis of textbook Project 5}

The first code, project presentation, was found in each unit and since there are six units, there were six activities connected to creating a project. Although the textbook itself does not suggest the task saying present your project, Teacher's Book (2010) advises to let learners present their work and practise performance before an audience. Projects in the textbook had different topics such as pop music, our country's educational programme, different regions of your country, teenage life in your country, how do people spend their money and ordinary people changing history. What we found interesting was the fact that the project activity was intended for individual work instead of group work. Furthermore, all projects required a longer process as there were instructions such as to conduct an interview with some teenagers and use audio/video recording. In some cases, project work even required applying research methods such as interviews or surveys. In all cases, learners were asked to put some pictures or graphs in the project. In one project task, they had to follow a pattern such as: Set the scene. How did the situation come about? What happened? What happened after the incident? What was the result? This pattern might help them during the presentation process to keep fluent speech.

The second code, presentation of ideas, found in each unit as well was always introduced with the title "Tell the class your ideas." Usually, the presentation of ideas came after the discussion task, in which one spokesperson performs a monologue concluding the discussed ideas. Six out of seven tasks were found in sections "Speaking" which is good evidence that the textbook gives the opportunity to practise performance skill and fluency as well. The last task was part of "English across the curriculum" section. What can be considered a disadvantage was the fact that these tasks involve a presentation performance from a few learners only.

The third code, storytelling, was identified only twice. Although there were many reading tasks which are usually followed by retelling a story, this textbook suggested some questions, which can foster the activity retelling a story. Fortunately, two speaking tasks for storytelling, which gave learners total freedom in creating the story, were detected. One of them was connected to the picture. There were three different pictures and each student was asked to choose one and create a story of their own. The second task asked learners to imagine they were a banknote, which is old and dirty. Their task was to create a story including the following pattern: your early life, your experiences and what will happen next. Learners could also practise using past simple, the present perfect and the future tense with will. The code number six, giving a speech, was not found in the textbook Project 5.

\section{Content analysis of textbook and workbook More! 3}

The activity, classroom presentation, representing the first code was found four times. The first activity was part of the "Communication" section where learners were asked to work in pairs and talk about films including a description of the actors, the director, the story itself and the special effects used in the film. After the pair work, the Teacher's Book suggests asking some learners to present their film in front of the whole class. The second, third and fourth presentations represent a postwriting activity. Learners are firstly asked to write a description of a person they know using as many adjectives as possible and then they should perform their descriptions in front of the class. In the third classroom presentation learners write a paragraph about their hometown and then present it 
out loud to the class. Furthermore, after the learners' presentations they are asked to decide whose presentation was the most interesting. The last spoken presentation focused on the topic "my invention" and followed the same procedure as the previous ones.

The second code, presentation of ideas, was a part of the "Writing" section, precisely a postwriting activity. However, in this case learners were asked to suggest some tangible ideas for solving the problems of recycling. Firstly, they were asked to choose one out of three problems, write an article and then present it to the class. The purpose of this activity was performing a persuasive speech to make the audience want to take action. This activity is quite demanding, but as it was found in Unit 11, which is the penultimate one, learners' proficiency might be challenged.

The third code, project presentation, was found only once as well. It was part of a "Culture" section introduced as a task called "Over to you!" The Purpose of the project was to enhance environmental awareness. Learners were asked to work in small groups, design a poster and a plan. After working on their projects, they were asked to present them to their class.

The fifth code, identified only once, was a review. As in the case of most performance tasks this one was found in the "Writing" section and was related to writing a film review. As the Teacher's Book suggests, although this task is primarily focusing on writing, teachers can ask learners to perform their review in front of the class. Furthermore, a review as an activity type mentioned by Richards (2008) corresponds with Talk as Performance. Learners are asked to include information about the actors, set, why you like/dislike it and do you recommend it? Why/Why not? The code number six, giving a speech, was not found in the textbook More! 3.

For the workbook More! 3 analysis the same coding system as in the textbooks was applied. Not many activities promoting speaking were expected in the workbook as they generally focus mainly on practising the writing skill. However, one activity type developing the function of speaking Talk as Performance was found in the workbook. The activity introduced as "Give a speech" was part of Speaking task found in section "Exam skill". Learners were supposed to write their ideas first and once they have finished; they should give a speech in front of the class. There are three situations suggested: earthquake, hurricane, and lightning storm, for which the learners must perform what their classmates or people in general should or shouldn't do. Additionally, some reasons must be provided by the learners.

\section{Observation analysis}

The second method, the purpose of which was to find out the reality of teaching speaking with a focus on the function of speaking Talk as Performance was an observation. In order to interpret the results of the observation, we created an observation sheet whose main category was function of speaking Talk as Performance. However, as the research progressed, we had to modify the original codes of the category, and we had to add a new category concerning any possible situations for developing the function of the speaking Talk as Performance. For better interpretation, Table 2, providing the system of categories and codes, inspired by Reid (2014), is applied for each school.

Table 2: Summary of observation analysis

\begin{tabular}{|l|l|l|}
\hline & School A & School B \\
\hline $\begin{array}{l}\text { Total number of observed } \\
\text { lessons: }\end{array}$ & 6 & 9 \\
\hline \multicolumn{2}{|c|}{ Category 1: Presence of Talk as Performance } \\
\hline \multicolumn{1}{|c|}{ Codes: } & Results: & Results: \\
\hline 1.YES & - & - \\
\hline 2. NO & & - \\
\hline 3. Activity type & - & - \\
\hline 4. Materials & - & - \\
\hline 5. Speaking as main activity & - & - \\
\hline 6. Speaking as an extra & - & \\
\hline
\end{tabular}




\begin{tabular}{|l|c|c|}
\hline activity & & - \\
\hline 7. Form of work & - & - \\
\hline \multicolumn{2}{|c|}{ Category 2: Potential Situations for Developing Function of Speaking Talk as Performance } \\
\hline TALK AS PERFORMANCE & $\begin{array}{l}\text { 2 (review about school event) } \\
2 \text { (retelling the story) }\end{array}$ & - \\
\hline
\end{tabular}

We did not observe any situation referring to Talk as Performance, neither at school A nor at school B. From the table, it can be seen that neither of the teachers implemented activities promoting the function of speaking Talk as Performance during the observed English lessons.

As for the category Potential situations for developing the function of speaking Talk as Performance, we managed to recognize four situations at school A and none at school B. Two of the situations were related to retelling the story, which was read and watched, and another two situations were connected to activities in which learners would give a review about a school event they experienced.

\section{Interview analysis}

The interviews were conducted at the end of the observations at both schools. The main aim was to find out about the teachers' attitude toward teaching speaking in general and the function of speaking Talk as Performance in particular. First, we tried to find out where the teachers perceive the importance of speaking and whether they have some special procedure for developing this skill. We were interested in whether they use the speaking activities provided in the textbooks or their own speaking activities and materials. Within the category function of speaking Talk as Performance we were interested in what types of activities the teachers use, and what the learners' attitudes towards these activities are. The interviews were based on 15 questions and lasted approximately 30 minutes. Answers from both teachers are analysed within each category and the codes below in Table 3 .

Table 3: Summary of interview analysis

\begin{tabular}{|c|c|c|}
\hline \multicolumn{3}{|c|}{ Category 1: Speaking in general } \\
\hline Codes: & School A & School B \\
\hline 1. Speaking skill & ability to communicate & $\begin{array}{l}\text { ability to speak and react in } \\
\text { some concrete situation }\end{array}$ \\
\hline 2. Importance/reason & \multicolumn{2}{|c|}{ very important } \\
\hline & $\begin{array}{l}\text { speaking as a tool to get } \\
\text { something done }\end{array}$ & $\begin{array}{l}\text { speaking as an ability } \\
\text { necessary for future life }\end{array}$ \\
\hline 3. Procedure of teaching speaking & \multicolumn{2}{|c|}{ following the order of tasks in textbook } \\
\hline 4. Speaking activities/techniques & $\begin{array}{l}\text { pair dialogues, role plays, } \\
\text { group, discussion }\end{array}$ & $\begin{array}{l}\text { pair dialogues, role plays, } \\
\text { pair discussion }\end{array}$ \\
\hline 5. Materials & textbook & textbook, picture \\
\hline $\begin{array}{l}\text { 6. Sufficient/Insufficient } \\
\text { occurrence of speaking activities } \\
\text { in textbook from teachers' point } \\
\text { of view }\end{array}$ & $\begin{array}{c}\text { insufficient, monotonous } \\
\text { activities }\end{array}$ & sufficient \\
\hline \multicolumn{3}{|c|}{ Category 2: Talk as Performance } \\
\hline Codes: & School A & School B \\
\hline 1. Activities & $\begin{array}{l}\text { reading journals, project } \\
\text { presentation, tell the class } \\
\text { your ideas, retelling the } \\
\text { read/listened story }\end{array}$ & project presentation \\
\hline $\begin{array}{l}\text { 2. Learners' attitudes, problems } \\
\text { and solutions }\end{array}$ & $\begin{array}{l}\text { Attitude: negative } \\
\text { Problem: lack of language } \\
\text { skill and being ashamed }\end{array}$ & $\begin{array}{l}\text { Attitude: depending on their } \\
\text { personalities } \\
\text { Problem: being ashamed, }\end{array}$ \\
\hline
\end{tabular}




\begin{tabular}{|l|l|l|}
\hline & $\begin{array}{l}\text { Solution: watching English } \\
\text { TV series and movies }\end{array}$ & $\begin{array}{l}\text { learning by heart } \\
\text { Solution: creating positive } \\
\text { atmosphere }\end{array}$ \\
\hline $\begin{array}{l}\text { 3. Sufficient/Insufficient } \\
\text { occurrence in textbook from } \\
\text { teachers' point of view }\end{array}$ & Insufficient \\
\hline
\end{tabular}

The first category focuses on the teachers' perception of teaching speaking in general. First code of this category reveals that teacher A sees speaking as an ability to communicate and teacher $B$ as an ability to speak and react in some actual situation. Both teachers agree that the speaking skill is very important which is represented by code number two. Teacher A provides the reason that speaking is a tool for getting something done and teacher B perceives speaking as a practical skill necessary for future life. However, teacher $B$ adds that the importance of speaking skill might differ depending on learners' ambitions, future job and personal interests. Code number three, referring to procedure of teaching speaking, provides information that both teachers usually follow the order of the textbooks' tasks providing an example how it should look like and then giving opportunities for practising and producing speaking by learners. Considering the code number four, activities which teachers use for speaking development, teacher A prefers work in pairs while practising dialogues and role plays activities. Moreover, she also uses group discussions with one speaker who concludes the discussed ideas. Teacher B prefers using dialogues, pair discussions and role plays. Both usually use only these types of activities and do not vary them. We were also interested in whether teachers use their own materials or the textbook only. Teacher A responded she mostly preferred using the textbook and only rarely tried something different and new. Teacher B confirmed using the textbook that she likes a lot, but she mentioned also using pictures in order to practise telling a picture story. However, at present she does not use it much. The code number six reveals that teacher $A$ perceives an insufficient occurrence of speaking activities in the textbook she uses. The reason she provided was the monotonous character of the activities. On the other hand, teacher B considered speaking activities in the textbook sufficient.

The second category, Talk as Performance, refers to the purpose of the activities, which is to maintain a longer monologue or public speech. Activities representing code number one reveal that teacher A uses the activity "reading journals" which learners are asked to write. Two or three learners per month are asked to prepare a presentation about a book they read. They must present an author, main characters, short plot overview and what they liked about the book. Another similar activity is presenting the project about their favourite singer. Both of these activities are teacher A's own production. She also named activities such as telling the class your ideas, where one of the learners presents the group's ideas after a group discussion. The last activity she mentioned was retelling a read story. Teacher B named only one activity, project presentation, but she immediately added that the textbook they used did not provide many tasks for project production. However, she said that she includes project presentation after every second or third unit on the topic such as family, school, sports and hobbies. As for code number two, teacher A responded that learners do not like being asked to provide a longer speech. According to her the reasons are lack of language skills and the feeling of being embarrassed. On the other hand, she adds that some of the learners also attend after-school language classes and she can observe that they have fewer problems in monologue production. As possible solutions she suggests watching English TV series and movies in order to promote fluency. Teacher B responded that learners' attitudes toward spoken performance depend on their personalities. Some of them are extrovert and like to be the focus of other learners' attention, but most of them act rather nervous while presenting. She considers feelings of anxiety and embarrassment as well as the habit of learners to learn the sentences, which are necessary for the project presentation by heart to be the main problems. As a solution she suggested creating a positive and supportive atmosphere in the classroom. Code number three was agreed by both teachers to be an insufficient occurrence in the textbooks they use. 


\section{Findings and discussion}

By applying the content analysis, we have found out whether the textbooks and the workbook used by 9th graders focus on promoting the function of speaking Talk as Performance. Furthermore, we tried to detect the type of these activities and the number of their occurrence. This way we could compare which textbook provides stronger representation of Talk as Performance. The content analysis revealed that Project 5 promotes this function mostly through activities such as project presentation, presentation of ideas, storytelling and classroom presentation. The textbook More! 3 includes activities such as presentation of ideas, projects and classroom presentation. We also found an activity "give a review activity", but the most surprising was the presence of the performance activity, "give a speech", in the workbook More! 3.

Moreover, by conducting the content analysis we are able to answer the first research question: Which activities in the analysed textbooks and workbook promote Talk as Performance? The function Talk as Performance was found in all three analysed materials with higher occurrence in Project 5. In total, 15 activities of three different types such as six project presentations, seven presentations of ideas and two storytelling activities were found. The textbook More! 3 provides seven activities in total of four different types as well. They consist of one project presentations, one presentation of ideas, four classroom presentations and one review activity. Furthermore, the workbook contributes with one activity called "give a speech."

The aim of interview was to find out the answer to the second research question: Do the teachers implement activities focusing on the function of speaking Talk as Performance? If yes, how do they implement them? If not, why they do not implement them? We were interested in which activities they use, what the learners' attitudes towards these activities are and whether they think the textbooks they use provide sufficient or insufficient amount of activities focusing on the function. Interviews also included questions referring to speaking in general. Both teachers agreed that the function Talk as Performance is the least taught and they think there is an insufficient amount of activities provided in the textbooks they use. We might agree with them since activities they named were mostly of their own production rather than those provided in the analysed textbooks. Teacher A named three activities such as reading journals, presentation of project, retelling the read or listened story. Teacher B named only one activity, project presentation, which she uses on her own initiative. They both agreed about the negative attitude of learners towards these activities, which according to them is the result of a lack of language knowledge and feelings of embarrassment.

\section{Conclusion}

We did not manage to observe any of the activities provided in the analysed textbooks and a workbook in real. On the other hand, we managed to recognize potential situations for developing the function Talk as Performance at school A. Two of them were reviewing a school trip and the remaining two activities represented storytelling. As we were informed, learners had a 9th graders prom during the period of conducting the observations. Moreover, they visited the Museum of Holocaust. From theory we know that one of the activities developing Talk as Performance is a review about a school event. We would suggest asking the learners to prepare a review, which they would present in front of the class in such a way that a person who did not attend the trip would be able to imagine what the trip was about. Two other potential situations focusing on Talk as Performance could be the activities retelling the stories. We observed that learners were asked to read short stories about England and in the last lesson before Christmas holiday they watched the movie A Christmas Carol. In order to promote their fluent speech and Talk as Performance, we would suggest asking them to prepare a short speech presenting what the stories were about.

The outcomes of the action research conducted by Kamenická and Kováčiková (2019) support these suggestions. They implemented the techniques with the emphasis on learners' engagement and emotional experience, when teaching EFL to teenagers and used stories in various contexts personal story, story-retelling etc. Their findings confirmed the assumptions that emotional engagement makes learning more comprehensible, enjoyable and fun. Furthermore, they also showed that learners experienced positive emotions and felt strongly motivated. 
To conclude the discussion of the research results, the limitations of the study have to be mentioned. At the beginning of the research, we expected to observe many activities promoting the function of speaking Talk as Performance as well as different ways of teaching them. However, after the first week of the observations we had to admit that these expectations would not be fulfilled for two reasons. The first one is that since the English learning and teaching process does not focus on speaking only and we did not explicitly ask the teachers to focus on speaking lessons, we observed them the least as both teachers followed the textbook in chronological order. Since the English teaching and learning process at primary school also includes developing the other three communicative skills as well as teaching grammar and vocabulary, which were arranged successively in the textbooks, we did not manage to observe a real speaking lesson at school A. Fortunately, we could observe a speaking lesson at school B. If we had explicitly asked the teachers to provide speaking lessons only, it would not be considered a natural choice of activities. The second reason, based on interviews with the teachers, is that many performance activities will be probably included at upper secondary school level.

\section{References}

Baumayer, K. (2019). What Is Public Speaking and Why Do I Need to Do It? Retrieved from https://study.com/academy/lesson/what-is-public-speaking-and-why-do-i-need-it.html.

Black, R. (2019). Glossophobia (Fear of Public Speaking): Are You Glossophobic? Retrieved from https://www.psycom.net/glossophobia-fear-of-public-speaking.

British Council http://learnenglish.britishcouncil.org/.

Brown, G., \& Yule, G. (1983). Teaching the Spoken Language. Cambridge: Cambridge University Press. Brown, H. (2004). Language Assessment: Principles and Classroom Practices. New York: Longman.

Budden, J. (2019). Motivating Teenagers. [online]. Retrieved from: $<$ https://www.teachingenglish.org.uk/article/motivating-teenagers.

Cohen, L., Manion, L. \& Morrison, K. (2007). Research Method in Education. New York: Routledge.

Council of Europe, Common European Framework of References for Languages: Learning, Teaching, assessment. (2011). Cambridge University Press.

Dörnyei, Z. (2005). The psychology of the language learner: individual differences in second language acquisition. New York: Routledge.

Gondová, D. (2013). Od gramatiky k hovoreniu. Bratislava: Metodicko-pedagogické centrum.

Hadfield, J., \& Hadfield, C.H. (2008). Introduction to Teaching English. New York: Oxford University Press.

Harmer, J. (2007). The practice of English Language Teaching, 4th ed.; New York: Longman ELT. Hutchinson, T. (2009). Project 5. Teacher's Book, 3rd ed.; Oxford: Oxford University Press. Hutchinson, T. (2010). Project 5. Student's Book, 3rd ed. Oxford: Oxford University Press..

International Standard of Classification: ISCED 2011. Retrieved from: <http://uis.unesco.org/sites/default/files/documents/international-standard-classification-ofeducation-isced-2011-en.pdf.

Jones, P. (1996). Planning an oral language program. In P. Jones (Ed). Talking to Learn. Melbourne: PETA, 12-26.

Kamenická, J., \& Kováčiková, E. (2019). Emotional Engagement in Teaching English Vocabulary. Praha: Verbum.

Lightfoot, A. (2019). Public Speaking Skill. Retrieved from: <https://www.teachingenglish.org.uk/article/public-speaking skills?fbclid=IwAR3N4tC6HfrBOFTuw4nfXVq_rM33nY008taUZz3OIz4R5Jm-EBk_qZO6Dz4.

Lindstromberg, S. (2004). Language activities for Teenagers. Cambridge: Cambridge University Press. Lower secondary teacher guide. (2006). Department of Education, Papua New Guinea.

Puchta, H., \& Stranks. J. (2014). More! 3. Student's Book, 2nd Ed. Cambridge: Cambridge University Press.

Puchta, H., \& Stranks. J. (2014). More! 3. Teacher's Book, 2nd Edition. Cambridge: Cambridge University Press. 
Puchta, H., \& Stranks. J. (2014). More! 3. Work Book, 2nd Edition. Cambridge: Cambridge University Press.

Reallyenglish: Teaching English to Teenagers. (2019). Retrieved from: <https://www.really-learnenglish.com/teaching-english-to-teenagers.html.

Reid, E. (2014). Intercultural Aspects in Teaching English at Primary Schools. Frankfurt am Main: Peter Lang Edition.

Richards, J. (2008). Teaching Listening and Speaking. From theory to practice. New York: Cambridge University Press.

Saumell, V. (2019). What are your top 5 tips for teaching teenagers? Retrieved from: $<$ https://www.teachingenglish.org.uk/blogs/vicky-saumell/what-are-your-top-5-tips-teachingteenagers-vicky-saumell.

Scrivener, J. (2011). Learning Teaching: The essential guide to English Language Teaching, 3rd ed. Oxford: Macmillan.

Skeffington, C. (2004). Getting teenagers talking. Retrieved from: $<$ https://www.teachingenglish.org.uk/article/getting-teenagers-talking.

Thornbury, S. (2005). How to teach speaking. United Kingdom: Pearson Education Limited.

Ur, P. (1996). A Course in Language Teaching: Practice and Theory. Cambridge: Cambridge University Press.

\section{Acknowledgements}

The paper includes research results gained as a part of the project 002UKF-4/2020 Positive Psychology in Teaching English. 